\title{
AN ANALYSIS OF THE FALL OF THE DEMOCRATIC PARTY OF JAPAN
}

\author{
Asmadi Hassan, Rohayati Paidi and Baizura Hanim Halim
}

\begin{abstract}
Democratic Party of Japan (DPJ) won the Lower House election in 2009 and became the first party that defeated the Liberal Democratic Party (LDP) in terms of the number of seats. The DPJ controlled both chambers, the Upper and Lower House when it formed a coalition government with the Social Democratic Party (SDP) and the People's New Party (PNP). However, the DPJ administration lasted merely three years and three months stretching from September 2009 to December 2012. The DPJ was badly defeated in the Lower House election in 2012, losing 75 percent of its seats. The party obtained only 57 out of 480 seats contested compared with the LDP that won 294 seats. Furthermore, eight of the DPJ cabinet members were defeated in the elections, including the finance minister. The former Prime Minister, Naoto Kan also lost his seat in the election, but he was saved by the Proportional Representative (PR) election system. The objective of this paper is to analyze the defeat of the DPJ in the Lower House elections in December 2012. Researchers argue that the change of the electoral system in 1994 which aimed at elevating the importance of manifestoes in the election as the main cause of the defeat of the party.
\end{abstract}

Keywords: Democratic Party of Japan, Liberal Democratic Party, election, manifesto, Upper House

\section{Introduction}

A history of Japan was recorded when the Democratic Party of Japan (DPJ) won the Lower House election in 2009. It was the first party that defeated the Liberal Democratic Party (LDP) in terms of the number of seats, to become the largest party in Japan. ${ }^{1}$ The DPJ controlled both chambers, the Upper and Lower House when it formed a coalition government with the Social Democratic Party (SDP) and the People's New Party (PNP). The success story of the DPJ beating the LDP that controlled the government for more than half a century was regarded as a significant political transformation in Japan. It was also considered a trust given to the DPJ to bring transformation in the Japanese politics, after a long period of governing by the LDP.

However, the DPJ administration lasted merely three years and three months stretching from September 2009 to December 2012. Table 1 shows the results of the Lower House elections from the years 2005 to 2012. It was clear that the DPJ was badly defeated in the Lower House election in 2012, losing 75 percent of its seats. The party obtained only 57 out of 480 seats contested compared with the LDP that won 294 seats. Furthermore, eight of the DPJ cabinet members were defeated in the elections, including the finance minister. The former Prime Minister, Naoto Kan also lost his seat in the election, but he was saved by the Proportional Representative (PR) election system.

1 Although LDP lost in the Lower House elections in 1993, it remained the biggest party in terms of number of seats in the Diet. 
Table 1: Results of the Lower House Elections from 2005 to 2012

\begin{tabular}{|l|c|c|c|}
\hline Party/Year & $\mathbf{2 0 0 5}$ & $\mathbf{2 0 0 9}$ & $\mathbf{2 0 1 2}$ \\
\hline DPJ & 113 & 308 & 57 \\
\hline SDP & 7 & 7 & 2 \\
\hline PNP & 4 & 3 & 1 \\
\hline NPN & 1 & 1 & 0 \\
\hline NPD & 1 & 1 & 9 \\
\hline TPJ & - & - & 294 \\
\hline LDP & 296 & 119 & 31 \\
\hline New Komeito & 31 & 21 & 0 \\
\hline NRP & - & 0 & 54 \\
\hline JRP & - & - & 8 \\
\hline JCP & 9 & 9 & 18 \\
\hline Your Party & - & 5 & 0 \\
\hline Others & 0 & 0 & 5 \\
\hline Independent & 18 & 6 & 480 \\
\hline Jumlah & 480 & 480 & \\
\hline
\end{tabular}

Abreviation: Democratic Party of Japan (DPJ), Social Democratic Party (SDP), People's New Party (PNP), New Party Nippon (PNP), New Party DAICHI (NPD), Liberal Democratic Party (LDP), New Renaissance Party (NRP), Japanese Communist Party (JCP), Tomorrow Party of Japan (TPJ), Japan Restoration Party (JRP). Modified from: Tsukasa Iga, "Politics of Regime Change under the One-party Dominant Rule in Japan: Lessons from the Rise and Fall of the Democratic Party of Japan," International Journal of East Asian Studies, Vol. 3, No. 1, 2013/2014, p. 20-21.

It was very embarrassing that the DPJ lost a large number of seats, decreasing from 308 in 2009 to 57 in 2012. Obviously, the voters who trusted the DPJ previously lost their faith in the party. The objective of this article is to analyze the defeat of the DPJ in the Lower House elections in December 2012. Researchers argue that the change of the electoral system in 1994 which aimed at elevating the importance of manifestoes in the election as the main cause of the defeat of the party. In other words, unfulfilled manifestoes of the party in the 2009 election were the cause of the defeat for the party.

\section{Theoritical Framework}

This study is related to political institutions and political behavior. Andrew Heywood argues that the institutional approach in analysis is to find the reality of politics through the study of the causes and consequences of political institutions. ${ }^{2}$ In order to understand and to explain political experiences, a study must begin with political institutions as the key factor of analysis. ${ }^{3}$ The utilization of the institutional approach allows a researcher to analyze the influence of institutional politics on party organizations, the political behaviors and the strategies of political actors.

2 Andrew Heywood, Key Concept in Politics, London: MacMillan Press, 2000, p 93.

3 Syed Ahmad Hussein, Pengantar Sains Politik, Kuala Lumpur: Dewan Bahasa dan Pustaka, 2006, p 19. 
Andrew Heywood argues that the institutional approach is a set of arrangements that govern the behaviors of individuals or groups of people based on rules and procedures. ${ }^{4}$ The institutional politics is formal in terms of character. Political institutions are defined as the rules of the game that shape political interactions. Douglas C. North argues that institutions are the rules of the game in a society or man made constraints that shape the interactions between them: “... the rules of the game in a society, more formally, are the humanly devised constraints that shape human interactions." ${ }^{5}$

Election is one of the important institutions as it is formal in nature. Since this study is related to the electoral system, it is significant to associate the institutional theory as a guide of study. Accordingly, this study applies the theory of institutions in the analysis. Brian Woodal argues that the rules of the game in an electoral system play an important role in shaping the nomination of candidates in elections: "electoral institutions - the rules of the game play a decisive role in shaping of candidate for elective office." ${ }^{6}$ In other words, the rules of the election influence the party system pertaining to the number of parties emerged to compete in inter and intra-party activities, the incentive for the parties to cooperate and appropriate approach to gain votes.

The electoral institutions approach has been adopted by political scientists including Maurice Duverger. Maurice Duverger in his study on the electoral system found that Single Member District (SMD) adopted in the United States and Britain tends to stimulate the formation of a two-party system - "the single ballot simple majority system favors the two-party system." 7 The result of the study was named Duvenger Law since voters would not cast their votes for a party that has no chance to win in an election. ${ }^{8}$ Politicians as well would join a political party that is able to win in an election for the sake of their political careers. ${ }^{9}$ As a result, those parties with no voters or politicians gradually would lose support and probably would be dissolved or merged with other parties; eventually, only two major parties would be formed. ${ }^{10}$

An institutional study provides clear evidence on what would happen when institutions change. In sum, the theoretical framework of this study is included in Figure 1.

Andrew Heywood, Key Concept in Politics, p 93.

5 Douglas C. North, Institutions, Institutional Changes and Economic Perfomance, Cambridge: Cambridge University Press, 1990, p. 3.

6 Brian Woodal, "The Politics of Reform in Japan's Lower House Electoral System," in Grofman Bernard, Sung Chull Lee, et.al., Election in Japan, Korea and Taiwan Under the Single Nontranferable Vote: The Comparative Study of Embedded Institution, Ann Arbor: University of Michigan Press, 1999, pp. 24-25.

7 Maurice Duverger, (translated by Barbara dan Robert North), Political Parties: Their Oganization and Activity in Modern State, London: Methuen \& Co Ltd, 1964, p. 217.

8 James N. Danziger, Understanding the Political World: A Comparative Introduction to Political Science, New York: Pearson Longman, 2009, p. 478.

9 Mark J. Ramseyer, Frances M. Rosenbluth, Japan's Political Marketplace, p. 35.

10 Michael G. Roskin, Robert L. Cord, James A. Medeiros, Walter S. Jones, Political Science: An Introduction, New Jersey: Pearson Education Inc, 2008, p. 210. 
Figure 1: Theoritical Framework

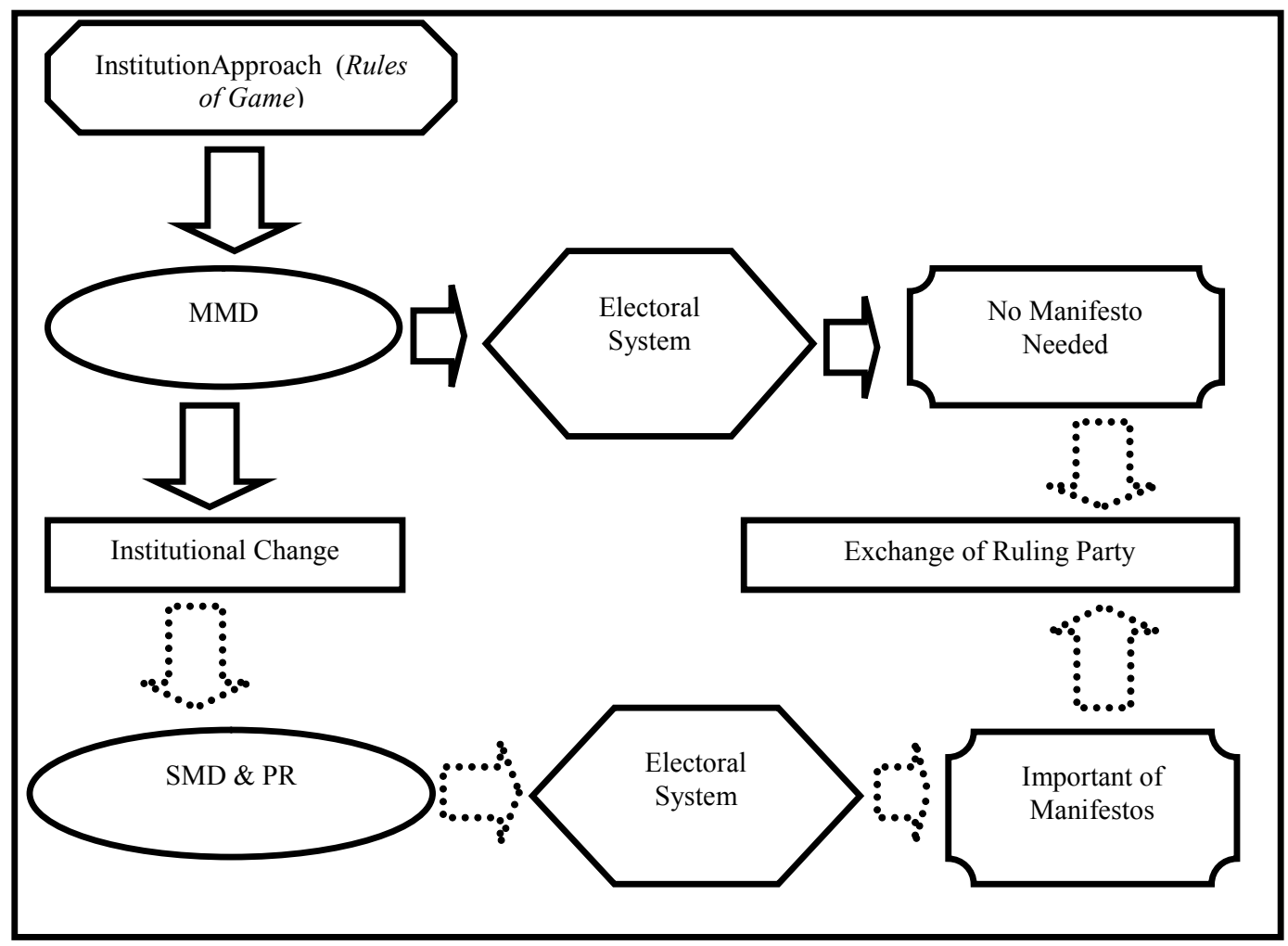

Sumber: Ilustrasi Pengkaji

Source: Researcher's Ilustration

The electoral system introduced in Japan in the year 1994 led to the importance of manifestoes compared with the previous electoral system. The new election system is a mix of PR and SMD to replace the Multi-Member District (MMD). The MMD adopted in Japan until the 1993 election was not manifestoes oriented in election campaigns. The MMD system which offered one to six seats in one constituency caused big party such as the LDP to contest with more than one candidate in a constituency. The candidates represented political factions (habatsu) in the LDP rather than the party. It caused the candidates to compete with one noother to win votes from the same group of voters. ${ }^{11}$ Eventually, manifestoes were not used in the election campaign, but candidates focused on support groups (koenkai) to garner personal votes. ${ }^{12}$ In lieu of the manifestoes, candidates promised gifts, favors and pork barrel politics to their supporters. ${ }^{13}$ Voters cast their votes based on personal gain, and not on the manifestoes offered by a party.

11 Haruhiro Fukui, Shigeko N. Fukai, "Campaigning for the Japanese Diet," in Bernard Grofman et.al, Election in Japan, Korea and Taiwan under the Single Non-Tranferable Vote, Ann Arbor: The University of Michigan Press, 1999, p 144-145.

12 Fukashi Horie, "Seiji Shisutemu to Senkyo Seido," in Fukashi Horie ed. Seiji Kaikaku to Senkyo Seido, Tokyo: Ashi Shobo, 2008, p 16.

13 Gifts, favors and pork, Refer to Steven R. Reed and Michael F. Thies, "The Causes of Electoral Reform in Japan," in Matthew Shugart, Martin P. Wattenberg, Mixed-Member Electoral Systems: The Best of Both Worlds? Oxford: Oxford University Press, 2003, p 155. 
Therefore, the MMD system encouraged orientation and alignments to candidates.In most cases in Japan, candidates with the ability to engage in pork barrel politics were more advantageous than candidates with no pork barrel politics. ${ }^{14}$ In sum, the MMD candidates emphasize the importance of personality, networking with support groups and the ability to offer personal service to their supporters rather than manifestoes. ${ }^{15}$

The effect of the MMD system was the existence of many political parties, and widespread corruption among politicians, who provided financial assistance to the supporters; there were no manifestoes oriented campaigns in the election. To overcome these problems, a mixed electoral system of SMD and PR was introduced in the year 1994. Both the election systems potentially influence political parties to merge and consequently to form a two-party system as argued by Durvenger Law. Voters are inclined to choose the party that could offer the best service to the constituency by issuing the best manifestoes. Personal network oriented campaigns of elections are replaced by manifestoes oriented campaigns, in line with the introduction of the new electoral system. Similarly, competition between party candidates as well as independent candidates will take place, rather than competition between political faction candidates, parties and independent candidates.

Accordingly, one of the basic premises of the electoral system is that the aim of producing manifestoes oriented election campaigns will be achieved. Other goals of the election system include the existence of competition between parties based on manifestoes as well as the formulation of manifestoes stressing on public and international interests. The new electoral system would also create more realistic options for voters; candidates would be able to explain their party's in-depth policies even more clearly to the voters. ${ }^{16}$ Hence, voters would be able to make an assessment and comparison of promises of different candidates and decide on their choice in the election. Accordingly, voters would not be confused with the campaigns of many candidates from one party since now they are required to obtain information from a candidate who represents a party.

Therefore, manifestoes are a significant tool in the mixed electoral system, SMD and PR; the knowledge of manifestoes enables voters to be aware of the policies that would be introduced when a party wins an election. On the other hand, political awareness is necessary to understand the current voters' behavior: they cast their votes based on manifestoes rather than personal ties. In sum, the new electoral system clearly emphasizes competition between parties and encourages manifestoes oriented campaigns by the political parties. ${ }^{17}$

With the manifestoes, the goal of the electoral system has been achieved. In fact, the manifestoes-based campaigns have replaced the previous election campaigns that emphasized personal appeal. ${ }^{18}$ Researchers discover that manifestoes in election

14 Patrick Kollner, "The Liberal Democratic Party at 50: Source of Dominance and Changes in the Koizumi Era", Social Science Japan Journal, Vol. 9, No. 2, 2006, p 246.

15 Hideo Otake, "Overview" dalam Otake Hideo edi., How Electoral Reform Boomeranged, Tokyo: Japan Center for International Exchange, 1998, p x.

16 Gary W. Cox, Frances Rosenbluth, "Anatomy of a Split: The Liberal Democrats of Japan," Electoral Studies, Vol 14, No. 4, p 372.

17 Ibid.

18 Ellis S. Krauss, Robert Pekkanen, "Reforming the Liberal Democratic Party" in Sherry L. Martin, Gill Steel, eds, Democratic Reform in Japan: Assessing the Impact, Boulder: Lynne Rienner, 2008, p 21. 
campaigns enable political parties, especially the ruling party, to be more accountable; this is very helpful for voters in making decisions. Secondly, voters can judge the performance of the winning party by how much it has delivered based on its campaign manifestoes. Should the promises in the manifestoes not fulfilled, the voters have another choice: vote for the opponent party in the next election. The new electoral system in fact helped the founding of the two-party system. The emergence of the DPJ by merging and annexation of many parties was a proof of the success of the new electoral system.

\section{DPJ Manifesto}

"Peoples's living first" was the slogan hailed by the DPJ in the Lower House election in 2009. Some reforms were set out in the DPJ manifestoes including basic education, international relations, health and retirement benefits, the relationship between local and central governments, as well as the relationship between politicians and bureaucrats. ${ }^{19}$ Specifically, the DPJ's manifestoes aimed at these aspects: ending the waste of public works; balancing the relationship between Japan and United States; control of bureaucrats by drafting legislation; and national policy decisions making in the hands of the cabinet. The DPJ also promised a welfare state, and no tax increase in its administration.

Despite a number of promises offered in the manifestoes, only a few of them were fulfilled. Eventually, unfulfilled manifestoes became a thorn in the party's administration. Two important manifestoes which DPJ failed to implement became the major factor causing the collapse of the DPJ. The first was the increase of consumer tax from five percent to eight percent in 2014 and to 10 percent in 2015. The second was the failure to move the United States military bases out of Okinawa (MCAS Futenma) to another prefecture in Japan or entirely out of Japan. Both manifestoes were closely related to the Japanese daily lives and would be greatly appreciated by the voters upon implementation.

\section{Increase of Consumer Tax}

The DPJ through its manifestoes promised a welfare state without a tax increase in its administration. The party was aware of the cost of social security and that the national debt would increase if the 2009 election manifestoes were to be implemented. However, the DPJ continued to champion the proposed manifestoes in order to win the election. During the election campaigns, the party president, Yukio Hatoyama actively promoted the matter to the voters. The party insisted it would not increase the consumer tax within four years of administration if they won the election.

When the DPJ won the election, Hatoyama became the Prime Minister of Japan; he kept the promise despite pressure from within the party to raise the consumer tax rate. However, after Hatoyama resigned, Naoto Kan who replaced him announced his plan to increase the consumer tax from five percent to 10 percent. Kan, a former finance minister in the Hatoyama cabinet, was responsible for maintaining the stability of the Japanese economy. He opined that an increase of consumer tax was the most effective way to avoid bankruptcy, strengthen the Japanese economy as well as the

19 Please refer to the DPJ homepage. 
social system. ${ }^{20}$ Furthermore the ruling DPJ administration was facing problems due to economic sluggishness, global financial crisis, shortage of younger people compared to older folks and a large national debt. These negative factors led the party desparetely to increase the consumer tax.

The consumer tax increase was later announced by Kan prior to the Upper House elections in 2010, which highlighted the financial reconstruction of Japan. ${ }^{21}$ As a result of the plan, the DPJ was punished by a loss of 11 seats from the original of 55; the party also lost its control over the Upper House. The election results clearly showed that the plan to increase the consumer tax was not well received by the voters. The defeat also was considered as an early signal that the DPJ must stick to its manifestoes in order to receive a mandate in the next election.

The consumer tax raising plan was also opposed by other leaders in the DPJ, especially those who wanted to keep the party's promises as detailed in the election manifestoes. Eventually the DPJ split into two groups. The first group consisted of the supporters of consumer tax raising plan headed by the Prime Minister Kan and senior leaders such as Katsuya Okada, Seiji Maehara and Senkoku Yoshito. The second group was the opposing faction led by an influential leader, Ichiro Ozawa. The divided DPJ eventually caused the weakening of the party.

When Yoshihiko Noda replaced Kan in August 2011, the economic situation became worse. Japan's debt reached 1000 trillion yen, which was two times the amount of its GDP. Noda took a firm stance to raise the consumer tax in order to balance the debt as well as to stablize the Japanese economy. The total amount of debt was larger than those of Greece and Italy which were facing a fiscal crisis recently. In the meantime, Japan was saddled with additional problems due to the earthquake, tsunami and nuclear plant leakage in the Tohoku region. Noda who used to be a finance minister in the Kan cabinet, recognized the importance of consumer tax raising in order to solve these problems. Therefore, Noda staked his career as Prime Minister for achieving the goals by increasing the consumer tax.

Ultimately, Noda managed to increase the consumer tax when the Lower House passed the bill on June 26, 2012 and the Upper House endorsed it on August 8, 2012 with support from the LDP and New Komeito. Noda failed to obtain consent from the Ozawa group but received support from the LDP, especially in the Upper House. Consequenly, Ozawa left the DPJ as a result of the failure to support the consumer tax increase. This departure affected the party's attractiveness, especially the lack of support from voters who rallied behind an influential leader such as Ozawa. Thus, without Ozawa, the DPJ further weakened. Noda's firmness to implement consumer tax raising also caused 49 of the DPJ Diet members to leave the party in July 2012. The group consisted of 40 members of the Lower House and nine from the Upper House; they were mainly Ozawa supporters. Ozawa played an important role behind the drafting of the manifestoes of the 2009 election; he was obviously disappointed with the decision to raise the tax. Ozawa believed the rising welfare costs can be accommodated by containing national waste. ${ }^{22}$

20 Tomohito Shinoda, Contemporary Japanese Politics: Institutional Changes and Power Shifts, New York: Columbia University Press, 2013, p 187.

21 Ibid, p 187.

22 Michael Cucek, "Ozawa's Departure, the Revival of the DPJ and the Future of Japan”, East Asia Forum, 5 July 2012. 
The LDP support was obtained after the DPJ agreed to accept the condition offered by the LDP, to dissolve the Lower House in the next season. Noda had been widely criticized for the agreement to raise the tax because the DPJ's manifestoes were set out with no tax increase. "Comprehensive Reform of Social Security and Tax System" was eventually introduced with the consumer tax rate raised from 5 percent to 8 percent in 2014 and to 10 percent in $2015 .^{23}$

Following his firmness to raise the consumer tax, public support for Noda declined. According to the poll carried out by the Nihon Keizai Shimbun, shortly after Noda was elected as the Prime Minister, his support was at 49 percent and non-support was at 42 percent. However, when Noda began feuding with the Ozawa group on consumer tax raising issue, the non-support increased to 56 percent in January 2012 and the support dropped to 36 percent. Whereas in July 2012, a poll carried out by the Nihon Keizai Shimbun showed that the support for Noda cabinet was at 28 percent and the DPJ was at merely 18 percent. ${ }^{24}$ The Asahi Shimbun polls on 7 and 8 July 2012 also found the support for him dropped to 25 percent. ${ }^{25}$

Politicians must be aware of the impact of the imposition of tax on the voters, as they could threaten their position as the ruling party. History showed that during the Ohira Masayoshi administration, he was defeated in the 1979 election when he tried to introduce consumer tax. Similarly in 1986 and 1994, when Yasuhiro Nakasone and Morihiro Hosokawa tried to introduce consumer tax, it led to the downfall of their administration. ${ }^{26}$ In sum, although these leaders were aware of the risk of tax increase, they tried to introduce the tax in order to stabilize the country's economy.

The contention on the issues of consumer tax in the long run undermines the consolidation of the party. For example, Prime Minister Kan was forced to resign after the Ozawa group threatened to support a no-confidence motion submitted by the LDP. This was the weakness of the DPJ, which was formed due to the background of various parties in Japan. In mid-2011, the DPJ was divided into two groups, the proponents and opponents of the consumer tax increase. The Ozawa group together with Hatoyama opposed the tax increase, while Yoshihiko Noda supported the tax increase.

\section{Relations with the United States}

As mentioned above, the DPJ's stand on the dealings with United States was to reevaluate the relations by adding "the equal relations between the two countries based on the principle of mutual trust." 27 To achieve these goals, the DPJ insisted that the 50-year-old Japan Security Treaty with the United States must be reviewed, especially in regard to the presence of United States military forces in Japan. Besides, the DPJ emphasized close relations with neighboring countries such as China and South Korea so as to balance Japan-United States relations. In order to realize these goals, the DPJ insisted that the United States military presence in Japan should be reduced. Hatoyama,

${ }^{23}$ Junghwan Lee, "DPJ Broken Promise and the End of the Anti-Koizumi Era in Japan", EAI Issue Briefing, No. MASI 2012-04, pp 4.

24 Ibid, p. 8.

25 Tomohito Shinoda, p. 224.

26 Junghwan Lee, p. 7.

27 Shinjidai no nichibei doumei no kakuritsu. Please refer to Jinbo Ken, "Gaikou.Anpo: Rinen tsuikyu kara genjitsu rousen he" in Nihon Saiken Inishiatiibu (cho), Minshuto Seiken Shippai no Kensho, Tokyo: Chukou Shinsho, 2012, p. 126. 
who was the DPJ President at that time, promised to move the United States military bases out of Okinawa should the DPJ win the majority of seats in the Lower House election in the year 2009.

Hatoyama's promise was well received by Okinawans. The poll conducted by the Mainichi Shimbun showed that 70 percent of the Okinawans supported the party. ${ }^{28}$ The promises affirmed by the DPJ gave hope to the Okinwans especially those who objected the previous proposal by LDP to relocate the MCAS Futenma to Henoko. ${ }^{29}$ With the effective campaign strategies, especially on the issue of the relocation of military bases in Okinawa, the DPJ won a large number of seats. The LDP however was rejected in the 2009 election since the voters believed that the transitional government would bring the Okinawa problems to an end. Upon winning the election, the relocation of MCAS Futenma became a major issue that needed to be resolved. If the issue was not resolved, it could potentially threaten either the relationship between Japan and the United States or lose the trust of the voters who had given the mandate to the DPJ. However, Hatoyama announced various statements that indicated he never had a clear plan on the matters related to the relocation.

For instance, in September 2009, Hatoyama stressed that the DPJ would review the Japan-United States agreement to relocate MCAS Futenma to another part of Japan or out of the country entirely. ${ }^{30}$ Similarly, in a report published by The Japan Times on October 10, 2009, he reiterated that the coalition government would retain the Hatoyama plans to review the relocation of MCAS Futenma out of Okinawa. However, a day before the report, Hatoyama agreed to relocate the military bases to other cities in Okinawa as agreed in the year 2006. In November 2009, Hatoyama insisted that Tokyo would reconsider the issue of the transfer despite the promises made in the election campaigns in the year 2009. ${ }^{31}$ However, The Japan Times reported on December 5, 2009 that Hatoyama agreed to relocate the MCAS Futenma to Guam as an option of new location for the United States military bases. ${ }^{32}$ Various statements released by Hatoyama showed his inconsistency on the issue of relocation of MCAS Futenma in Okinawa.

In addition, Hatoyama had to juggle to meet the obligations to three different groups of people. The first was to fulfil the promise given to the Okinawans during the election campaign in the year 2009. The second was the need to preserve a good relationship with the party in the coalition government, the Social Democratic Party (SDP); the SDP had called for the moving of MCAS Futenma out of Okinawa. The third was the adoption of an agreement signed between Japan and United States in the year 2006; the implementation of this agreement was expected to resolve the issue of United States military bases. Finally, on May 4, 2010, Hatoyama admitted that he was unable to fulfil the promises given to the Okinawans; he decided to designate Henoko as the most suitable location for MCAS Futenma. The Japanese government then issued a joint

28 “Thousands of Japanese Protest U.S Base Plan", Reuters, 8 November 2012.

29 Eric Johnson, "Opposition to MCAS Futenma move won't go away", The Japan Times, 19 Oct. 2009.

30 "MCAS Futenma Stance the Same: Hatoyama", The Japan Times, 26 September 2009.

31 "Demo of 21,000 People Demand Closure of MCAS Futenma Air Base", The Japan Times, 9 November 2009.

32 "Hatoyama Cabinet Confirms U.S. Base Relocation Accord must be Reviewed", The Japan Times,10 Oktober, 2009. 
statement with the United States in May 2010 relating to the transfer of MCAS Futenma to Henoko as agreed in in the year 2006.

Hatoyama's failure to deliver on his promise resulted in a decline of his popularity from 75 percent ${ }^{33}$ right after being elected to less than 20 percent. ${ }^{34}$ The poll conducted by Nikkei Inc.- TV Tokyo Corp. on April 23-25, 2010 revealed a mere 24 percent ${ }^{35}$ support, and on May 28-30, 2010 it showed that the rating had decreased to only 22 percent. ${ }^{36}$ Similarly, Daily Yomiuri in its June 2010 poll discovered a continued slide of support towards Hatoyama in which only 19 per cent was recorded. ${ }^{37}$ Not only did he lose support, but under the Hatoyama administration, the Japan-United States relationship deteriorated due to the absence of a solution on the issue of MCAS Futenma.

Hatoyama eventually resigned after 266 days $^{38}$ or less than nine months in office. His resignation was due to criticisms over his failure to keep the promises made during the election campaigns to relocate MCAS Futenma at least out of Okinawa. ${ }^{39}$ Hatoyama's failure was very disappointing to many people including the Okinawa Governor, Nakaima who trusted his capability to relocate the United States military bases. In fact, before Hatoyama resigned, he held a joint press conference with a United States representative stating that the plan to relocate MCAS Futenma to Henoko would remain as per the signed agreement in 2006. The United States maintained its stand that regardless of whoever was at the helm, the Japanese government must honour the agreement because it was made between governments, not between politicians. ${ }^{40}$ This matter is crucial in order to maintain the mutual trust between two governments. ${ }^{41}$

Hatoyama's unfulfilled promise became a thorn in the flesh for his successor, Naoto Kan. Kan who was elected on June 4, 2010, needed to solve the problem of relocation of MCAS Futenma wisely in order to restore the DPJ's credibility. However, Hatoyama's unfulfilled promise left a detrimental impact on the DPJ.$^{42}$ An example of this predicament was that when the DPJ decided not to put up candidates in the upper house election in July 2010 in Okinawa due to the lack of support. ${ }^{43}$ In fact, the MCAS Futenma relocation problem had actually worsened under the Hatoyama administration, and it continued in similar fashion under Kan's administration.

In his speech as the Prime Minister in the Japanese Diet, Kan stressed that the relocation of MCAS Futenma was a major challenge for his cabinet. ${ }^{44}$ Based on the speech, it can be concluded that Kan was determined to focus on solving the MCAS

33 Mai Iida, "DPJ's Second Wind Worries Rivals", The Japan Times, 1 July 2010.

34 Jun Hongo, "Hatoyama Quits as Prime Minister", The Japan Times, 3 June 2010.

35 "PM's Dithering Fuels Distrust of Politics", The Nikkei Weekly, 6 May 2010.

36 "In with an Aprroval Rating Bang, out with a Whimper", The Nikkei Weekly, 7 June 2010.

37 "Approval Rate for Hatoyama Cabinet Hits New Low of 19\%", The Daily Yomiuri, 1 June 2010.

38 "Kan Steps into Raging Tempests", The Nikkei Weekly, 7 June 2010.

39 John Brinsley, Isabel Reynolds, "DPJ Blows Chance to Establish Two Party Rule", The Japan Times, 18 December 2012.

40 "Futenma Deal 'will be Respected': Pentagon", The Japan Times, 3 June 2010.

41 "Delayed Futenma Decision Posing Multiple Crises", 14 December 2009.

42 "Kan Steps into Raging Tempests", The Nikkei Weekly, 7 June 2010.

43 "No Okinawa Candidate", The Japan Times, 16 June 2010. Also refer to Mariko Yasumoto, "Hatoyama Legacy Bedevils DPJ in Okinawa", The Japan Times, 8 July 2010.

44 "Kan Hints He Won't be Signing Off on Futenma Plan for Months", The Japan Times, 3 August 2010. Also refer to Itaru Oishi, "Futenma Threatens to Fade Smiles”, The Nikkei Weekly, 5 July 2010. 
Futenma problem in his administration while restoring Okinawans' trust for the DPJ. On the other hand, the selection of Kan as the Prime Minister was considered the best opportunity to start over the relations between the central government and Okinawa, as well as Japan-United States relations. As described above, the Japan-United States relations were at its worst during the Hatoyama administration owing in large part to his promise to relocate MCAS Futenma out of Okinawa. After taking over the administration, Kan's policy tended to restore to the normal Japanese foreign policy, particularly to have good relations with the United States.

Kan's administration started off with his admission of the Japan-United States relationships being the main axis of Japan's foreign policy; at the same time he was committed to ease the Okinawans' burden in hosting the United States military bases. ${ }^{45}$ Kan's strategy was to continue the relocation process of MCAS Futenma to Henoko as he mentioned to Nakaima on June 15, 2010 as well as to transfer 8000 United States troops from Okinawa to Guam. In fact, Kan adopted the 2006 agreement signed by Tokyo and Washington. ${ }^{46}$

Kan's decisions disappointed the Okinawans. Nakaima stressed that the relocation of MCAS Futenma in Okinawa was still very difficult to implement due to the objections of the Okinawans and himself. ${ }^{47}$ In the mean time, a number of Okinawans who used to support the DPJ could not decide which party to vote for in the upper house election in July 2010; this was disclosed by The Japan Times in an interview with female voters in the district of Naha. Here is a good example: one 63 years old Okinawan woman initially put her trust in the DPJ to change the situation in Okinawa but she grew frustrated with the party's inability to fulfil its promise; consequently she was undecided on which party to vote for in the election. Meanwhile, an Okinawan man, Masatsugu Kitano in an interview expressed his cynical view of the DPJ; he said the party talked big but could not deliver its promise. ${ }^{48}$ Similarly, in an interview with the Okinawans during a research field trip, researchers found that the respondents in Okinawa insisted that they were neglected in the decision making process related to the relocation of MCAS Futenma by the DPJ. ${ }^{49}$

Hence, in order to win seats in the upper house elections in 2010, all opposition candidates stood against the relocation to Henoko. For example Aiko Shimajiri; an incumbent from the LDP, Hiroji Yamashiro; an independent candidate supported by the SDP and Tadayuki Ijyu representing the Japanese Communist Party (JCP) all opined that the MCAS Futenma should be moved out of Okinawa. ${ }^{50}$ On August 26, 2011 Kan resigned as prime minister and he was replaced by Yoshihiko Noda. The Futenma transfer problem was still unresolved despite two prime ministers at the helm of the administration consecutively.

After assuming as the third DPJ Prime Minister, Yoshihiko Noda adopted policies which were inclined towards the continuation of those of his predecessor, which aimed

45 "Mr. Kan States his Approach", The Japan Times, 12 June 2010.

46 "Japan must be Firm with Russia, China", The Nikkei Weekly, 22 November 2010.

47 "Futenma Plan Firm, Kan Tells Nakaima", 16 June 2010.

48 John Brinsley, Isabel Reynolds, "DPJ Blows Chance to Establish Two Party Rule", The Japan Times, 18 December 2012.

49 Interview with Okinawans on 16-20 December 2013 in Naha, Okinawa.

50 Mariko Yasumoto, "Hatoyama Legacy Bedevils DPJ in Okinawa", The Japan Times, 8 July 2010 . 
to restore the close diplomatic relations with the United States. ${ }^{51}$ In the meantime Noda continued to ease tensions with the Okinawans who were perturbed at the unresolved issue of the MCAS Futenma relocation. His stand was made clear by his statements in relation to the MCAS Futenma relocation problems in Okinawa.

In September 2011, immediately after he was entrusted with the premiership, Noda visited Okinawa for the first time and insisted that the central government would stick to the original agreement reached in the year 2006. He promised however, that the MCAS Futenma would not remain in Ginowan; but rather it would be relocated to other areas to ease the burden of the Okinawans. ${ }^{52}$ During his visit, Noda attempted to address the protest staged by the Okinawans by explaining the detailed plan of the central government, the relocation to Henoko and the transfer of some United States troops from Okinawa to Guam.

On the diplomatic front, Noda maintained that strengthening the relations with the United States was significant in his administration, following Japan's increasingly strained relations with its neighbouring countries such as China and North Korea. As described earlier, there was tension in Tokyo-Beijing relations over territorial disputes regarding the islands of Senkaku. For example in 2010, the Japanese authorities arrested Chinese fishermen who allegedly intruded into the Senkaku Islands area. China responded by suspending ministerial-level meetings as well as cultural relations between the two countries. China also cancelled deliveries of rare earths to Japan. The Japanese government finally relented and released the fishermen. Researchers argue that events such as these serve as a form of warning to Japan to strengthen the Japan-United States relations in order to balance China's military strength. Therefore, it was significant for Japan to maintain the United States military presence in Japan. ${ }^{53}$ Retention of MCAS Futenma via relocation to Henoko was significant to restore good relationship between the two countries.

Under Noda's administration, Japan-United States relations remain an important policy. Noda supported the close ties with the United States due to his background as the son of a former Japanese defence forces (GSDF) and he took a firm stand against China on the territorial disputes. The Senkaku Islands territorial dispute had caused tension in the region and the presence of the United States military forces was significant in protecting the Japanese territory. Hence, the United States military presence in Okinawa not only served as counter-balancing element against China's military modernization, but was also related to the security issues in the East Asia region and sea routes. The importance became more apparent when the Chinese fishing vessels intruded into the Japan-controlled Senkaku Islands, which prompted action and counter-action from both countries. This conflict triggered an unhealthy relationship between Japan and China. Noda therefore argued on the significance of the Japan-United States relations in helping Japan defend her sovereign territory. South Korea which is similarly a close United States ally in East Asia also supported the retention of MCAS Futenma in Okinawa,

51 Shuhei Kuromi, Takashi Imai, "Many Hurdles in Rebuilding Alliance", The Daily Yomiuri, 7 February 2012.

52 "Nakaima Tells Noda to Give Up Nago Plan", The Japan Times, 28 February 2012. Also refer to "Noda Flies to Okinawa to Plea Case on Futenma", The Nikkei Weekly, 5 Mac 2012; "Noda must Improve Ties with Okinawa to Solve Futenma", The Daily Yomiuri, 1 Mac 2012.

53 Hiroyuki Akita, "Security Policy too Vital to Trifle with; Parties must put Aside Partisan Games, Tackle Key Issues like Futenma”, The Nikkei Weekly, 20 July 2010. 
particularly to strengthen the security of the country from the threat of North Korea and the expansion of China's military modernization.

It was clear that Noda supported the 2006 agreement, a policy similar to that adopted by the LDP. ${ }^{54}$ Despite the tension with Japan over the relocation of MCAS Futenma, the United States maintained the necessity of its presence in Okinawa, especially for the sake of regional security. China showed her true colours on the Japan seas which served as a key necessitating point for the U.S. military presence in Japan.

In sum, the DPJ under the administration of Yukio Hatoyama, Naoto Kan and Yoshihiko Noda strongly supported alliance between Japan and the United States. The DPJ administration eventually maintained the relocation of MCAS Futenma in Okinawa. Failure to move MCAS Futenma out of Okinawa had led to the resignation of Hatoyama on June 2, 2010. Hatoyama's support dropped to $20 \%$ from $75 \%$ and consequently resigned from his office after only less than nine months' administration. The decision to maintain military bases in Okinawa had led to the paralysis of the coalition party when the SDP withrew from the coalition on 30 May 2010. A high percentage of support for the DPJ administration at the beginning indicated high expectations of the voters. However, the DPJ failed to deliver the promises and it caused the percentage of support to plummet; this was a clear indication that the voters were disappointed with the ruling government.

The MCAS Futenma relocation issues were still pending and became a thorn in the DPJ administration. The DPJ's inconsistent stance on the relocation of MCAS Futenma not only caused the voters to give up on the party but also the Okinawans to feel discriminated and isolated from other prefectures.

\section{Conclusion}

The Institutional theory as applied in this study argued that manifestoes were a significant part in the mixed election system in Japan, comprising SMD and PR. Through the electoral system, there was a potential for the formation of the two-party system; both parties would compete with each other to obtain votes. Therefore, the formulation of realistic manifestoes is significant in order to ensure practical realization. Failure to implement those manifestoes would cause voters to switch to the rival party.

Therefore, it can be concluded that the main factor for the collapse of the DPJ was the failure to keep the promises as contained in the election manifestoes, especially those related to the Okinawa issue as well as the consumer tax increase. The failure of the DPJ administration to honor the election pledges within the three years consequently led to the rejection of the party by the voters. In fact, the DPJ's ability to resolve the issue of MCAS Futenma was reduced due to the weakening of public support. The DPJ lacked the sensitivity to hear "the silent voices" of the voters who were dissatisfied with its administration. This was proven two weeks before the Lower House election when a poll conducted by the Yomiuri Shimbun showed that the main opposition, LDP received 19\% support while the DPJ received only $13 \% .{ }^{55}$ Besides, the DPJ lacked the number of seats prior the the elections, 230 seats compared with 308 in the year 2009.

54 Alex Martin, Eric Johnston, “Noda pro-U.S. but Past Remarks may Haunt Asia Ties”, The Japan Times, 30 August 2011.

55 Japan Opposition LDP still Ahead in Polls, but Ruling DPJ Closing Gap, The Japan Times, 2 December 2012. 
The decreace in the number of seats was due to the fact that many of its members left the party to form a new party.

The three years' administration showed a weakness of the DPJ: three prime ministers resigned and were replaced consecutively, and there were frequent reshuffles of the cabinet. The DPJ weakness existed during Hatoyama's term of office and persisted during the terms of another two prime ministers. The DPJ administration could not function effectively due to internal conflicts of the party; the administrative machinery gradually deteriorated. In May 2013, the DPJ, then the opposition party, organized a convention by inviting 500 voters under the age of 30 to criticize the party's three-year administration. The convention was held with the initiative of young leaders of the party to find out why they were rejected in the last election. In a question addressing the DPJ mistakes, the attendees agreed that the party did not analyze the nature of the promises. The party was too ambitious in handing out promises which could not be fulfilled.

The DPJ's experiences are very useful to the political parties in Japan; they certainly can learn lessons from the DPJ mistakes. In order to be successful in the Japanese politics, a party must gain the trust of voters, as well as maintain accountability and responsibility in running the machineries of the government. 